Theatre Research in Canada

Recherches théâtrales au Canada

\title{
HEATHER DAVIS-FISCH, ed. Canadian Performance Histories and Historiographies: New Essays on Canadian Theatre, Volume 7. Toronto: Playwrights Canada Press, 2017. 433 pp.
}

\section{VK Preston}

Volume 39, Number 1, 2018

URI: https://id.erudit.org/iderudit/1055479ar

DOI: https://doi.org/10.7202/1055479ar

See table of contents

Publisher(s)

Graduate Centre for the Study of Drama, University of Toronto

ISSN

1196-1198 (print)

1913-9101 (digital)

Explore this journal

Cite this review

Preston, V. (2018). Review of [HEATHER DAVIS-FISCH, ed. Canadian Performance Histories and Historiographies: New Essays on Canadian Theatre, Volume 7. Toronto: Playwrights Canada Press, 2017. 433 pp.] Theatre Research in Canada / Recherches théâtrales au Canada, 39(1).

https://doi.org/10.7202/1055479ar

All Rights Reserved (c) Theatre Research in Canada / Recherches théâtrales au Canada, 2018
This document is protected by copyright law. Use of the services of Érudit (including reproduction) is subject to its terms and conditions, which can be viewed online.

https://apropos.erudit.org/en/users/policy-on-use/ 
primarily clarifies differences between Chekhov and Meyerhold, Jonathan Pitches misses the opportunity to mine the similarities between these two great inciters of the imagination, especially with regard to the grotesque, the actor's "duality of consciousness" (I4), and the spectator as co-creator. The book's scattered references to Futurism, eccentrism, and commedia dell'arte lay tantalizing breadcrumbs for additional research on Chekhov and Russian avant-garde theatre.

It is a strength, not a weakness, however, that the book leaves room for readers to become co-creators of future scholarship and practice. An essential complement to publications that focus on practical Chekhov exercises, The Routledge Companion to Michael Chekhov promises to become a standard guide-especially in the wake of its more affordable paperback release in 20I8 - for students, artists, and scholars of Chekhov's work, as well as for readers interested more broadly in Russian theatre, acting pedagogy, and the unleashing of the creative imagination.

\section{HEATHER DAVIS-FISCH, ed.}

\section{Canadian Performance Histories and Historiographies: New Essays on Canadian Theatre, Volume 7.}

Toronto: Playwrights Canada Press, 2017. 433 pp.

\section{VK PRESTON}

Canadian Performance Histories and Historiographies, edited with a strong introduction by Heather Davis-Fisch, throws down a methodological gauntlet with critiques of nationalism and the writing of history in theatre and performance studies in Canada. This cohort of fresh, critical approaches challenges a "maturation" trope of theatre's growth as a form "new" to the country, taking up sources from unproduced manuscripts, oral histories, and burlesques to using methods that demonstrate past exclusions in national theatre historiography. DavisFisch's curation of these essays turns on the prefix "re" as it offers a three-part organization: "(Re)integrations," "Returns and Re-examinations," and "Rethinkings" (italics mine). The book's organization thus foregrounds marginalized sources and untold histories with calls to retool approaches in performance research.

"Interventions into the Maw of Old World Hunger," the edited transcript of a brilliant roundtable by Jill Carter (Anishinaabe / Ashkenazi), Karyn Recollet (Cree), and Dylan Robinson (Stó:lō), will doubtless be received by the field as a key text. Challenging the ways settler scholars have adopted and appropriated Indigenous methodologies, Robinson addresses the Truth and Reconciliation Commission as amachine that gathers stories" (227), offering critiques of testimony, extractivism, and scophilia embedded in the TRC's digitized and streaming structures of memory and feeling. Activating dance imaginaries and Cree conceptions of both human and non-human shapings of knowledge, Recollet beautifully seeds creative possibility and memory in practices of "active and ongoing refusal" (2I2), asserting more-than-human choreographies from stars to stones (213). Thickening this conversation, Jill Carter turns towards the Anishinaabe prophecy of the eighth fire, an account of Odawa values and storytelling. "Conciliation" activates relationship and performance, she 
discerns, whereas "reconciliation" implies returning to a relationality that has never been honored or in place. "Embedded in the 'archive' (the story) and in the 'repertoire' (its telling) are seven Odawa values," Carter explains: "Love, Honour, Respect, Truth, Trust, Compassion, and Patience" (219). The storyteller does not stand apart from stories of creation, Carter observes, she "somatically discharges a theory of being" (220).

From the chiac dialect embraced in Nicole Nolette's writing on class activism and theatre in Acadia to Michelle Laflamme's potent history of Aboriginal theatre in Canada centring the work of Margo Kane, the volume emphasizes, as Laflamme writes, a "ten thousand year legacy of performance practices that include orature, ceremony, song and culturally embedded performances," addressing the urgency of revitalizing "traditional modes of performativity" (94). Yves Jubinville, in a contribution on Quebec theatre studies, retraces francophone research, past and present. Interrogating a swelling "tide of performance and cultural studies that swept the Anglo-Saxon world” (250), he illuminates Quebec scholars' concern that such disciplinary shifts drown out the community's research and historiographical contributions. Jubinville shows that language communities can and do arrange disciplines in incommensurate ways, proposing an "infra-history" of theatre culture's distinct societies (252).

Attending to theatre's role in what Marlis Schweitzer describes as the tools of empire reveals the shape of disciplinary genealogies. By taking up records of professional women and child artists performing between Canadian and Caribbean ports, Schweitzer's analysis offers a counterpoint to the historiography of military and garrison performances as "origins" of Canada's theatrical practice. The study interrogates Canadian reception of a hemispheric turn in performance studies, including unease that Americas-wide methods re-center US scholarly influence. Placing her study in the flux of such debates, Schweitzer's retracing of these ship-borne performances offers a gendered counterpoint to theatre histories forged in the garrisons' armed occupation of land. To mark this apparent dialogue with the methods of Elizabeth Maddock Dillon's New World Drama: The Performative Commons in the Atlantic World, I649-I849 (2014), Schweitzer's move redirects preoccupation with nationhood in theatre historiography to the question of oceanic and performative commons, also indicating, as scholars including Charmaine Nelson highlight, Canada's cross-geographic entanglements with the Atlantic plantocracies and slave trade.

Inseparable from such methodological and geographic turns, gender is an important, critical axis of the volume. Jessica Riley's study of dramaturgy reads archives of works in revision to reveal the displacement of women's voices and accounts of sexual violence in drafts of David Freeman's controversial play on disability and rebellion, Creeps (I97I). Alongside Riley's compelling account of such gendered erasure through processes of new play development, Robin Whittaker's work offers legacies of French language and Quebecois plays and translations left out of Toronto theatre historiography. Observing that women's student and amateur performance groups, unlike men's, have largely been omitted from national stories of theatre's emergence, Whittaker's work illuminates the historiographical as well as disciplinary impacts of sidelining histories shaped in sex-segregated universities and student associations. Teasing out terms and texts underpinning the field, Glen Nichols's analysis of theatre pedagogy in universities also calls for reexamining delineations of practice and theory that organize curricula. 
Alan Filewod's "Affect and the Unproduced" studies the manuscript "Glory Hole," penned in World War I trenches (and yet never performed). The essay is a treasure trove of insights and contributions, addressing traumatic memory, tricky evidence, and positivist historiographical tendencies in Canadian theatre studies. Alexandra Kovacs scrutinizes cross-cultural assumptions about theatre in historiography, holding up to view unmarked scripts underlying historians' accounts of E. Pauline Johnson. Tracing attempted governmental control of Indigenous cultural practices as well as Canada's Massey Commission, Allana Lindgren approaches the ideological scope of omitting dance sources in national theatre history, addressing colonial silences in light of the Indian Act and national institutions' assimilationist tendencies.

Reframing an early history of blackface caricature in Canada, Stephen Johnson delves into a proto-history of minstrelsy in the north by way of documents penned by protesters in nineteenth-century Toronto, citing the significance of opposition and protest by black communities in the I83os to defamatory performances. Reading the community's petition against these acts of "base ridicule" while unfolding genealogies of racialized caricature, this study of touring acts in clown and circus addresses pre-histories of blackface minstrelsy in popular, transnational North American performance. By contrast, Nikki Cesare Schotzko's call to "detextualize" performance historiography attends to translations and digital performance practices in recent works by queer, Asian, and Latinx artists.

Despite such contributions on archives' and memories' redistribution, the collection of essays in this volume largely skirts the Pacific and global south, missing opportunities for scholarly and artistic contributions engaging in diasporic, trans-, and transnational research. Such performance historiography's polyvocality would greatly benefit from wider dialogue with writing by scholars and creators of colour. As we pass such vexed anniversaries as "Canada I50," Schweitzer's invitation to "unpick" the threads of national theatre histories reflects the momentum to attend with greater vision to the potency of story and its elisions. With disciplinary analysis held up to new scrutiny, these essays expose emerging forms of historiography, genealogy, and return that reveal, as Robinson powerfully articulates, that "sovereignty is a practice that we do" (208). 